\title{
The Isolation and Structure of C4, the Fourth Component of Human Complement
}

\author{
IRMA GIGLI,* INGE VON ZABERN† and RODNEY R. PORTER \\ Medical Research Council Immunochemistry Unit, Department of Biochemistry, \\ University of Oxford, South Parks Road, Oxford OX13QU,U.K.
}

(Received 10 December 1976)

\begin{abstract}
The fourth component of complement, $\mathrm{C} 4$, was isolated from human serum in good yield, and in confirmation of previous reports was shown to be formed from three peptide chains, $\alpha, \beta$ and $\gamma$, with apparent mol.wts. 90000,80000 and 30000 respectively. Preparative methods are described for the isolation of the three peptide chains and their amino acid analyses reported. Component $\mathrm{C} 4$ contains $7.0 \%$ carbohydrate, $\alpha$-chain $8.6 \%$ and the $\beta$-chain $5.6 \%$. The $N$-terminal amino acid sequences are given for 12 residues of the $\alpha$-chain, eight of the $\beta$-chain and 19 of the $\gamma$-chain.
\end{abstract}

Initiation of the activation of complement in blood by antibody-antigen complexes is principally through the classical pathway in which the first component, $\mathrm{C} 1, \ddagger$ is activated, and this in turn converts components $\mathrm{C} 2$ and $\mathrm{C} 4$ into forms which interact, giving rise to the complex proteinase $\overline{\mathrm{C} 4-\mathrm{C} 2}$, also known as $\mathrm{C} 3$ convertase (reviewed by Reid \& Porter, 1975). Little is known of the structure and activity of the $\overline{\mathrm{C} 4-\mathrm{C} 2}$ complex, and to investigate this a study has been made of the isolation and structure of component C4. Earlier work (Schreiber \& Müller-Eberhard, 1974; Cooper, 1975; Nagasawa \& Stroud, 1976) has shown that component $\mathrm{C} 4$ is a protein of $200000 \mathrm{~mol}$.wt., with three peptide chains, $\alpha, \beta$ and $\gamma$, of apparent mol.wts. 93000,78000 and 33000 respectively.

Electrophoretic heterogeneity, probably due to a structural polymorphism, has been reported in component C4 of human serum (Rosenfield et al., 1969) and much interest has been aroused by the observation that component $\mathrm{C} 4$ of mouse serum may be identical with the Ss protein, a polymorphic serum protein which is linked genetically with the major histocompatibility complex (Meo et al., 1975; see also

\footnotetext{
* Present address: New York University Medical Center, Skin and Cancer Unit, 562 First Avenue, New York, NY 10016, U.S.A.

$\uparrow$ Present address: Max-Planck-Institut für Experimentelle Medizin, Abteilung Biochemische Pharmakologie, Herrmann-Rein-Strasse 3, 3400 Göttingen, Germany.

$\ddagger$ Abbreviations: the nomenclature of complement components and subcomponents is that recommended by the World Health Organization (1968). Activated components are indicated by a bar, e.g. $\bar{C} 4$. i $\operatorname{Pr}_{2} P-F$, di-isopropyl phosphorofluoridate; dansyl, 5-dimethylaminonaphthalene-1-sulphonyl.
}

Lachmann et al., 1975; Curman et al., 1975). Subsequently evidence has been given that a component-C4 structural gene maps in this complex (Teisberg et al., 1976). As the activated component $C 4$ has been shown to bind to cell surfaces (Budzko \& Müller-Eberhard, 1970; Patrick et al., 1970), this raises the possibility that it may also be concerned in the complex cellular interactions involved in an immune response.

In the present paper, simple methods are described for the preparation in good yield of component $\mathrm{C} 4$ and also of its three polypeptide chains. Many but not all of the previous reports on their structure have been confirmed and additional information has been obtained.

\section{Materials and Methods}

\section{Materials}

Chemicals were obtained as follows: $\operatorname{iPr}_{2} P-F$, Sigma (London) Chemical Co., Kingston-uponThames, Surrey, U.K.; mannitol and hexosamine hydrochlorides, BDH, Poole, Dorset, U.K.; neutral sugars and sialic acid standards, Sigma; prepacked columns for g.l.c., Phase-Sep, Queensferry, Clwyd, Wales, U.K.; sodium dodecyl sulphate, BDH; toluene-p-sulphonic acid, 3-(2-aminoethyl)indole hydrochloride and silylating reagents, Pierce and Warriner, Chester, U.K.; iodo $\left[1-{ }^{14} \mathrm{C}\right]$ acetamide $(60 \mathrm{mCi} / \mathrm{mmol})$, The Radiochemical Centre, Amersham, Bucks., U.K.; DEAE-Sephadex A-50, Sepharose 6B, CL-Sepharose 6B and Sephadex G-200, Pharmacia Fine Chemicals, Uppsala, Sweden; Dowex 1 (X8; 200-400 mesh) Sigma; hydroxyapatite (DNA grade), Bio-Gel HTP, Bio-Rad Laboratories, Bromley, Kent, U.K. 
Outdated human plasma after cryoglobulin precipitation was obtained from the Churchill Hospital, Oxford. $\mathrm{CaCl}_{2}$ was added to $20 \mathrm{~mm}$ and the plasma left to clot overnight at $4^{\circ} \mathrm{C}$. The clot was centrifuged down $(2000 \mathrm{~g}, 30 \mathrm{~min})$ and the serum stored at $-20^{\circ} \mathrm{C}$.

\section{Haemolytic assay of component C4}

Gelatin/veronal buffers were prepared as described by Nelson et al. (1966). Dilutions $(0.5 \mathrm{ml})$ of component $\mathrm{C} 4$ were incubated at $30^{\circ} \mathrm{C}$ with $0.5 \mathrm{ml}$ of erythrocytes $\left(10^{8} / \mathrm{ml}\right)$ sensitized with antibody and $\mathrm{Cl}$, the first component of complement. After addition of component $\mathrm{C} 2$, the haemolytic reaction was completed by addition of $1 \mathrm{ml}$ of guinea-pig serum diluted $1: 15(\mathrm{v} / \mathrm{v})$ in $0.04 \mathrm{M}$-EDTA in gelatin/veronal buffer; then $4.5 \mathrm{ml}$ of cold $0.15 \mathrm{M}-\mathrm{NaCl}$ was added after incubation for $1 \mathrm{~h}$ at $37^{\circ} \mathrm{C}$ and the mixture was centrifuged. The degree of lysis was measured by reading the $A_{410}$ of the supernatant. Results were expressed in $50 \%$-lysis (H50) units multiplied by the number of erythrocytes per $\mathrm{ml}\left(10^{8}\right)$ and referred to the titre of a standard serum stored at $-70^{\circ} \mathrm{C}$.

\section{Electrophoresis in polyacrylamide gel}

This was performed with buffers containing sodium dodecyl sulphate, as described previously (Gigli et al., 1976).

\section{Protein determination}

In the preparation of component $\mathrm{C} 4$, the protein concentration of column eluates was followed by measuring the $\boldsymbol{A}_{\mathbf{2 8 0}}$. In the separation of the peptide chains by chromatography on hydroxyapatite, $\boldsymbol{A}_{\mathbf{2 8 0}}$ could not be used, owing to interfering substances, and protein was measured by the method of Lowry et al. (1951) as modified by Hartree (1972).

\section{Preparation of component $C 4$}

Frozen serum $(500 \mathrm{ml})$ was thawed and, after addition of $1 \mathrm{ml}$ of $2.5 \mathrm{M}$-i $\operatorname{Pr}_{2} P$-F in propan-2-ol, was centrifuged at $23000 \mathrm{~g}$ for $30 \mathrm{~min}$ at $4^{\circ} \mathrm{C}$. The supernatant was poured into 2 litres of water at $4^{\circ} \mathrm{C}$ containing $5 \mathrm{~mm}-\mathrm{CaCl}_{2}, 2.5 \mathrm{~mm}$-phenanthroline and $2.5 \mathrm{~mm}$-iodoacetamide. The $\mathrm{pH}$ was adjusted to pH 7.4 with $1 \mathrm{M}-\mathrm{NaOH}$ and $0.5 \mathrm{ml}$ of $2.5 \mathrm{M}-\mathrm{iPr}_{2} P-\mathrm{F}$ added. The suspension was stirred at $4^{\circ} \mathrm{C}$ for $2 \mathrm{~h}$ and then centrifuged at $23000 \mathrm{~g}$ for $30 \mathrm{~min}$, the euglobulin precipitate being taken for the preparation of component C1 (Gigli et al., 1976). Then $1 \mathrm{ml}$ of $2.5 \mathrm{M}$ ${ }_{1} \operatorname{Pr}_{2} P$-F was added to the supernatant and $0.5 \mathrm{M}-$ $\mathrm{HCl}$ added to adjust the solution to $\mathrm{pH}$ 5.5. After stirring for $15 \mathrm{~min}$, the precipitate was removed by centrifugation and the supernatant adjusted back immediately to $\mathrm{pH} 8.6$ by adding $1 \mathrm{M}$-Tris. $\mathrm{NaCl}$ was added to give 0.185 . The solution from two preparations (total volume 5 litres) was passed through a column $(7 \mathrm{~cm} \times 27 \mathrm{~cm})$ of DEAE-Sephadex A-50 equilibrated with $0.01 \mathrm{M}$-Tris/ $\mathrm{HCl}(\mathrm{pH} 8.6) / 0.185 \mathrm{M}$ -
$\mathrm{NaCl} / 0.02 \% \mathrm{NaN}_{3}$. The column was washed with 6.5 litres of the same buffer until the $A_{280}$ of the eluate had fallen to 0.06 . Then $600 \mathrm{ml}$ of $0.01 \mathrm{M}$-Tris/HCl (pH 8.6) $/ 0.2 \mathrm{M}-\mathrm{NaCl} / 0.02 \% \mathrm{NaN}_{3}$ was run through the column, after which the remaining protein was eluted by a gradient formed by mixing $700 \mathrm{ml}$ of $0.01 \mathrm{M}$-Tris $/ \mathrm{HCl}(\mathrm{pH} 8.6) / 0.2 \mathrm{M}-\mathrm{NaCl} / 0.02 \% \mathrm{NaN}_{3}$ and $700 \mathrm{ml}$ of $0.01 \mathrm{M}-\mathrm{Tris} / \mathrm{HCl}(\mathrm{pH} 8.6) / 0.23 \mathrm{M}-\mathrm{NaCl} /$ $0.02 \% \mathrm{NaN}_{3}$. Elution with the latter buffer was continued until no further protein was eluted. The flow rate was about $300 \mathrm{ml} / \mathrm{h}$ during the washing of the column and was decreased to about $100 \mathrm{ml} / \mathrm{h}$ during the gradient elution. The fractions containing component $\mathrm{C} 4$ (Fig. $1 a$ ) were pooled, concentrated by ultrafiltration to $15 \mathrm{ml}$ and then $\operatorname{PPr}_{2} P-F$ was added to $1 \mathrm{~mm}$. This solution was passed through a column $(5 \mathrm{~cm} \times 90 \mathrm{~cm})$ of Sepharose 6B in $0.01 \mathrm{M}$-Tris/HCl (pH 8.6) $/ 0.2 \mathrm{M}-\mathrm{NaCl} / 0.02 \% \mathrm{NaN}_{3}$. The fractions containing component $\mathrm{C} 4$ (Fig. 1b, Pool 1) were pooled and concentrated, ${ }_{\mathrm{iPr}} P$-F was added to $5 \mathrm{~mm}$ and the mixtures were stored at $2^{\circ} \mathrm{C}$.

Separation of the polypeptide chains of component $C 4$ The component-C4 solutions were dialysed against

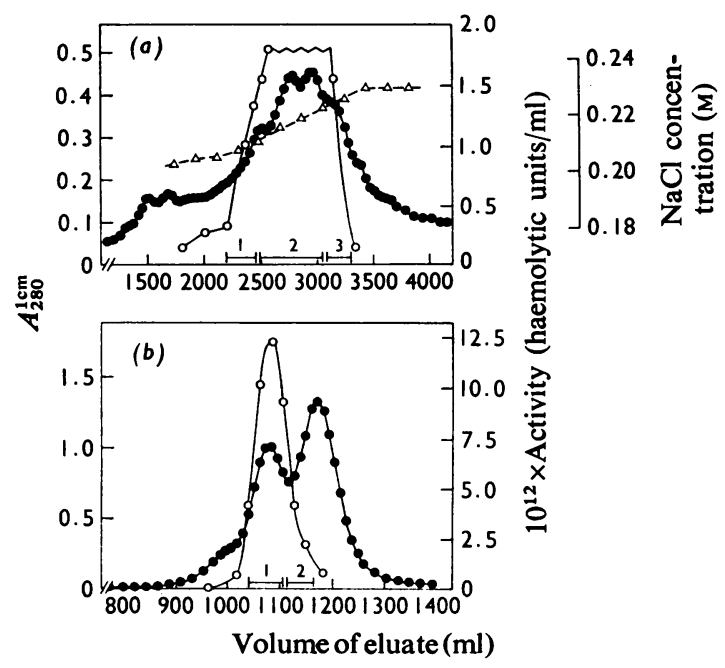

Fig. 1. Chromatography of component C4

(a) On a DEAE-Sephadex A-50 column ( $7 \mathrm{~cm} \times$ $27 \mathrm{~cm}$ ), 5 litres of the pH 5.5 supernatant was loaded and eluted with buffer containing $0.01 \mathrm{M}-\mathrm{Tris} / \mathrm{HCl}$, $\mathrm{pH} 8.6$, and increasing concentration of $\mathrm{NaCl}$. Active fractions were pooled as shown. $\bullet, A_{280} ; O$, component- $\mathrm{C} 4$ haemolytic units; $\triangle, \mathrm{NaCl}$ concentration (M). (b) Pool 2 shown in Fig. 1(a) above was concentrated to $15 \mathrm{ml}, \operatorname{iPr}_{2} P-F$ added to $1 \mathrm{~mm}$ and the mixture loaded on the Sepharose $6 \mathrm{~B}$ column $(5 \mathrm{~cm} \times$ $90 \mathrm{~cm})$ in buffer containing $0.01 \mathrm{M}-\mathrm{Tris} / \mathrm{HCl}(\mathrm{pH} \mathrm{8.6)/}$ $0.2 \mathrm{M}-\mathrm{NaCl} / 0.02 \% \mathrm{NaN}_{3} . \bullet, A_{280} ; \bigcirc$, component-C4 haemolytic units. 
$0.5 \mathrm{M}$-Tris/ $\mathrm{HCl}, \mathrm{pH} 8.6$, then dithiothreitol was added to $20 \mathrm{~mm}$ and the mixtures were incubated at $37^{\circ} \mathrm{C}$ for $2 \mathrm{~h}$. Iodo[ $\left.1{ }^{-14} \mathrm{C}\right]$ acetamide $(67 \mu \mathrm{Ci} / \mathrm{mmol})$ was added to $50 \mathrm{~mm}$. After standing for a further $30 \mathrm{~min}$ at room temperature $\left(16-18^{\circ} \mathrm{C}\right)$, the solution was dialysed against $0.25 \mathrm{M}$-Tris/ $\mathrm{HCl}, \mathrm{pH} 8.6$, at $4^{\circ} \mathrm{C}$ and then against $0.01 \mathrm{M}$-sodium phosphate, $\mathrm{pH} 6.4$, containing $2 \%$ sodium dodecyl sulphate, and finally against the same phosphate buffer containing $0.1 \%$ sodium dodecyl sulphate. The peptide chains were separated on a hydroxyapatite column $(1.4 \mathrm{~cm} \times 35 \mathrm{~cm})$ equilibrated with the same buffer. After loading and washing with this buffer the chains were eluted by a gradient formed from $500 \mathrm{ml}$ of $0.2 \mathrm{M}$-sodium phosphate (pH6.4)/0.1\% sodium dodecyl sulphate and $500 \mathrm{ml}$ of $0.5 \mathrm{M}$-sodium phosphate $(\mathrm{pH} 6.4) / 0.1 \%$ sodium dodecyl sulphate as described by Moss \& Rosenblum (1972). The eluate was screened by protein determination (Fig. 2) and by polyacrylamidegel electrophoresis in buffers containing sodium dodecyl sulphate, and the fractions containing each of the separated chains were pooled and concentrated. Each was dialysed against $0.05 \mathrm{M}$-sodium phosphate, pH 7, with Dowex $1(\mathrm{X8})$ resin in a dialysis bag also in the vessel, to facilitate the removal of the sodium dodecyl sulphate (Lenard, 1971).

An alternative technique was also used in which the $\gamma$-chain was separated from the $\alpha$ - and $\beta$-chains by fractionation on a column $(2.6 \mathrm{~cm} \times 95 \mathrm{~cm})$ of Sephadex G-200 equilibrated with 6M-guanidine hydrochloride, $\mathrm{pH}$ 7.0. Component $\mathrm{C} 4$ was reduced and alkylated, as described above, before dialysis into $6 \mathrm{M}$-guanidine hydrochloride. Separation of the $\alpha$-and

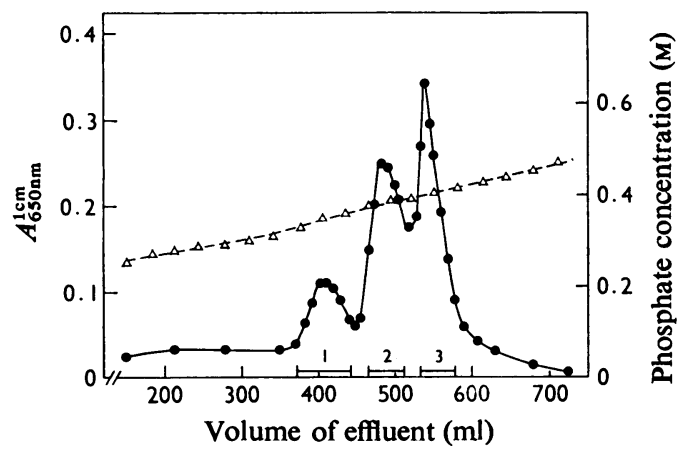

Fig. 2. Chromatography of component-C4 peptide chains Component-C4 polypeptide chains were separated by chromatography of $22 \mathrm{mg}$ of reduced and alkylated component $\mathrm{C} 4$, on a column $(35 \mathrm{~cm} \times$ $1.4 \mathrm{~cm}$ ) of hydroxyapatite in buffer containing $0.1 \%$ sodium dodecyl sulphate and increasing concentrations of sodium phosphate, pH6.4. •, Protein concentration by Lowry method $\left(A_{650}\right) ; \Delta$, phosphate concentration. $\beta$-chains necessitated repeated recycling through a column $(2.6 \mathrm{~cm} \times 90 \mathrm{~cm})$ of CL-Sepharose $6 \mathrm{~B}$.

\section{Amino acid and carbohydrate analysis}

Amino acid analysis was carried out as described by Reid (1974), with $1 \%$ phenol added to the constantboiling $\mathrm{HCl}$ (Sanger \& Thompson, 1963) and also $0.05 \%$ 2-mercaptoethanol if carboxymethylated proteins were hydrolysed. Hydrolysis in $3 \mathrm{M}$-toluene-psulphonic acid was used for determination of tryptophan (Liu \& Chang, 1971) as well as hexosamines (Allen \& Neuberger, 1975). For determinations of cystine and cysteine, component $\mathrm{C} 4$ was oxidized with performic acid (Hirs, 1956) and cysteic acid measured after hydrolysis. The peptide chains were reduced fully by incubation in $50 \mathrm{~mm}$-dithiothreitol/6 M-guanidine hydrochloride/ $0.3 \mathrm{M}$-Tris $/ \mathrm{HCl}$, $\mathrm{pH} 8.6$, for $3 \mathrm{~h}$ at $37^{\circ} \mathrm{C}$. Iodoacetamide was added to $250 \mathrm{~mm}$ and the solution left at $0^{\circ} \mathrm{C}$ for $1 \mathrm{~h} . S$ Carboxymethylcysteine was determined after hydrolysis. Neutral sugars and sialic acid were determined by g.l.c. after methanolysis (Clamp et al., 1971). Samples containing 6-8nmol of protein and $50 \mathrm{nmol}$ of mannitol as internal standard were incubated at $90^{\circ} \mathrm{C}$ for $6 \mathrm{~h}$ in $1.5 \mathrm{M}-\mathrm{HCl}$ in anhydrous methanol. The $O$-trimethylsilyl ethers of the methyl glycosides were detected in a Hewlett-Packard 5830 A gas chromatograph with a single column $(200 \mathrm{~cm} \times 0.32 \mathrm{~cm})$ of $3 \%$ SE-30 Ultraphase on Chromosorb AW-DCMS 85-100 mesh.

\section{$N$-Terminal amino acid determination and automatic sequencing}

$N$-Terminal amino acids were determined by the dansyl procedure (Gray, 1972) and dansyl-amino acids resolved by t.l.c. on polyamide sheets (Woods \& Wang, 1967). $N$-Terminal amino acid sequencing of the peptide chains after carboxyamidomethylation with iodo[ $\left[1{ }^{14} \mathrm{C}\right]$ acetamide was done in a Beckman $890 \mathrm{C}$ sequencer by using $0.1 \mathrm{M}$-Quadrol [0.1 M- $N N N^{\prime} N^{\prime}$-tetrakis-(2-hydroxypropyl)ethylenediaminetrifluoroacetate, $\mathrm{pH}$ 9.5], programmed as described by Brauer et al. (1975). Thiazolinones released were converted into phenylthiohydantoin derivatives, which were identified by t.l.c. and g.l.c. or amino acid analysis after hydrolysis with $\mathrm{HI}$ as described by Reid (1976). Release of radioactivity into the butyl chloride phase collected by the sequencer was determined by liquid-scintillation counting. A $0.3 \mathrm{ml}$ portion was added to $15 \mathrm{ml}$ of 1,4-dioxan containing $0.5 \%(\mathrm{w} / \mathrm{v}) \quad 2,5$-diphenyloxazole and $2 \%(w / v)$ naphthalene.

\section{Results}

\section{Preparation of component $C 4$}

As in the preparation of component $\mathrm{Cl}$ (Gigli et al., 1976), repeated addition of proteolysis inhibitors

Vol, 165 
was found necessary to obtain component $\mathrm{C} 4$ in good yield, and $\operatorname{iPr}_{2} P-F$ was the most effective inhibitor. The recoveries of component $\mathrm{C} 4$ at each step in the purification, as judged by haemolytic activity, were $80-90 \%$, except from the final column of Sepharose $6 \mathrm{~B}$, when the recovery was about $50 \%$; the lower values shown for the chromatography steps were not due to loss of activity but to selection of fractions to avoid impurities running close to the component C4 peak. Higher yields could be obtained if adjacent fractions were pooled and re-run, and this procedure was normally used (Table 1). The component $\mathrm{C} 4$ preparation obtained after fractionation on the DEAE-Sephadex A-50 and Sepharose 6B columns still contained $5-10 \%$ contaminating proteins as judged by polyacrylamide-gel electrophoresis. It was sufficiently pure to use for the isolation of the peptide chains on hydroxyapatite columns, as the contaminants were lost during the subsequent fractionation, but, for analysis of the whole protein as well as for purification of the chains by gel filtration, rechromatography on a small DEAE-Sephadex A-50 column by using a similar gradient to that used before gave a product with barely detectable impurities (Plate 1). The isolated component $\mathrm{C} 4$ was stable at $4^{\circ} \mathrm{C}$ in solutions containing $0.05 \% \mathrm{NaN}_{3}$ over months, but freezing of solutions led to precipitation.

\section{Reduction and alkylation of component $C 4$}

Component $\mathrm{C} 4$ was partially reduced under nondissociating conditions, if desirable, followed by complete reduction in $6 \mathrm{M}$-guanidine hydrochloride. If reduction was carried out in solutions containing $6 \mathrm{M}$-guanidine hydrochloride or $2 \%$ sodium dodecyl sulphate, partial fragmentation of the $\alpha$-chain was observed, giving rise to polypeptides with apparent mol.wts. of 42000 and 53000, as judged from electro- phoresis in gels containing sodium dodecyl sulphate. The degradation might be due to a trace proteinase that is insensitive to heat and ${ } \operatorname{Pr}_{2} P$-F but sensitive to dithiothreitol; prior reduction under nondissociating conditions prevents this fragmentation.

\section{Isolation of the polypeptide chains of component C4}

The $\gamma$-chain was separated easily from the $\alpha$ - and $\beta$-chains by exclusion chromatography in dissociating solvents, as it is of substantially lower molecular weight. Chromatography on columns of CLSepharose 6B in 6M-guanidine hydrochloride also gave a separation of the $\alpha$-and $\beta$-chains if they were recycled repeatedly. This is, however, a tedious method, and only $50 \%$ of the protein gave $\alpha$ - and $\beta$ chains free of each other even after recycling seven times, as might be expected when their molecular weights differ by less than $20 \%$.

More effective was the method described by Moss \& Rosenblum (1972) for separating protein subunits by using chromatography in sodium dodecyl sulphate solution on columns of hydroxyapatite. The peptide chains of component $\mathrm{C} 4$ dissociate fully in this solvent, and a satisfactory separation of the three chains was obtained in good yields (Fig. 2, Plate 1). The postulated molecular weight (Schreiber \& Müller-Eberhard, 1974) should give protein yields of $\alpha-: \beta-: \gamma$-chains in the proportions $1: 0.85: 0.35$, and elution of the three chains from the hydroxyapatite column gave yields in the proportions $1: 1: 0.5$. As the estimation of molecular weight was based only on the rate of movement during polyacrylamide-gel electrophoresis, and the $\alpha$ - and $\beta$-chains are not fully resolved on the hydroxyapatite column, these results are in reasonable agreement with the proposal that component $\mathrm{C} 4$ contains one of each of the three chains.

Table 1. Fractionation of component $C 4$ from serum

The preparation was carried out with $995 \mathrm{ml}$ of serum. Yields in parentheses show total yields of component $\mathrm{C} 4 \mathrm{from}$ a preparation starting with $500 \mathrm{ml}$ of serum.

\begin{tabular}{|c|c|c|c|c|c|c|}
\hline Procedure & $\begin{array}{l}\text { Resulting } \\
\text { fraction }\end{array}$ & $\begin{array}{c}\text { Total } \\
\text { volume } \\
\text { (ml) }\end{array}$ & $\begin{array}{l}\text { Total } \\
\text { protein } \\
\text { (mg) }\end{array}$ & $\begin{array}{c}\text { Total } \\
\text { activity } \\
\text { (haemolytic } \\
\text { units) }\end{array}$ & $\begin{array}{c}\text { Specific } \\
\text { activity } \\
\text { (haemolytic } \\
\text { units) }\end{array}$ & $\begin{array}{c}\text { Total } \\
\text { yield } \\
(\%)\end{array}$ \\
\hline- & Serum & 995 & 48110 & $4.39 \times 10^{15}$ & $9.12 \times 10^{10}$ & 100 \\
\hline Euglobulin precipitation & Supernatant & 5143 & 47070 & $3.80 \times 10^{15}$ & $8.07 \times 10^{10}$ & $87(91)$ \\
\hline pH5.5 precipitation & Supernatant & 5198 & 43130 & $3.54 \times 10^{15}$ & $8.21 \times 10^{10}$ & $81(80)$ \\
\hline Chromatography on DEAE- & Eluate pool 1* & 259 & 62 & $2.00 \times 10^{14}$ & $3.23 \times 10^{12}$ & \\
\hline Sephadex & $\begin{array}{l}\text { pool } 2 \\
\text { pool } 3\end{array}$ & $\begin{array}{l}567 \\
220\end{array}$ & $\begin{array}{r}230 \\
81\end{array}$ & $\begin{array}{r}14.72 \times 10^{14} \\
3.30 \times 10^{14}\end{array}$ & $\begin{array}{l}6.40 \times 10^{12} \\
4.07 \times 10^{12}\end{array}$ & $46(64)$ \\
\hline $\begin{array}{c}\text { Chromatography on } \\
\text { Sepharose 6B }\end{array}$ & Eluate & 68 & 62 & $7.18 \times 10^{14}$ & $1.16 \times 10^{13}$ & $16(32)$ \\
\hline
\end{tabular}

* Eluate pools 1 and 3 from the DEAE-Sephadex column were re-run on the same column and active fractions combined with pool 2. Similarly, less pure fractions from the Sepharose 6B column were rerun and combined with the most active fraction. The reported yields represent the sum of high-specific-activity component $\mathrm{C} 4$ and the re-run fractions. 


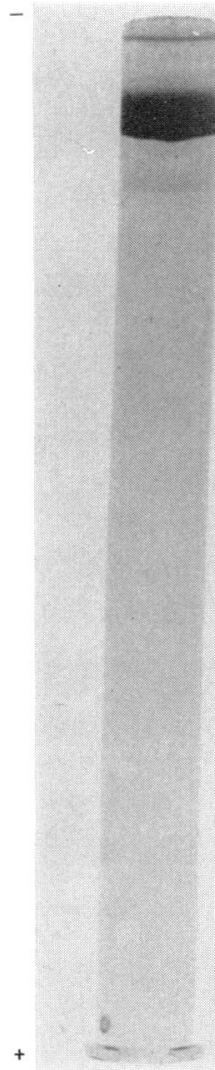

(a)

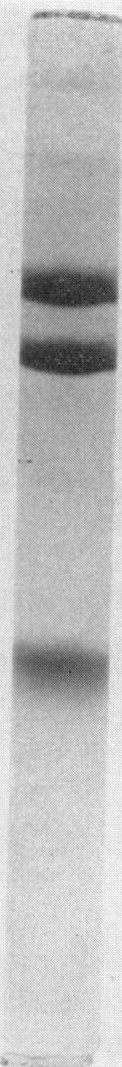

(b)

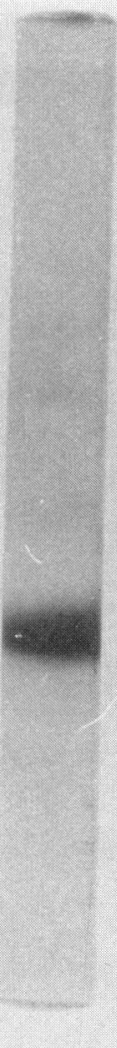

(c)

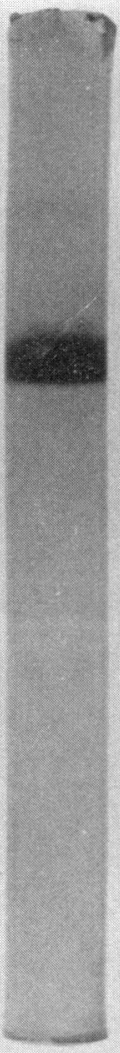

(d)

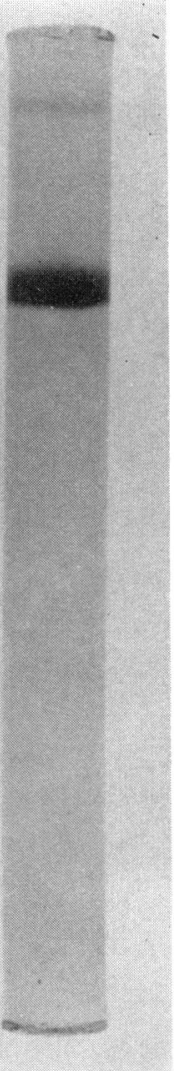

(e)

EXPLANATION OF PLATE I

Electrophoresis of component $C 4$ and its peptide chains

Electrophoresis on $5.6 \%$ polyacrylamide gel of component $\mathrm{C} 4$ and its peptide chains in buffers containing sodium dodecyl sulphate. Component C4, after chromatography twice on DEAE-Sephadex A-50 and once on Sepharose 6B, (a) unreduced and $(b)$ reduced; $(c) \gamma$-chain, $(d) \beta$-chain, $(e) \alpha$-chain from pools 1,2 and 3 respectively shown in Fig. 2. 


\section{Amino acid and carbohydrate analysis}

Analyses of the whole protein and the peptide chains of component $\mathrm{C} 4$ are given in Table 2. The overall pattern of amino acid residues is similar in the three chains, though there are some striking differences, such as the content of half-cystine and isoleucine in the $\gamma$-chain compared with that in the $\alpha$ and $\beta$-chains. In general the amino acid contents of the $\alpha$ - and $\beta$-chains are rather similar to one another and obviously different from that of the $\gamma$-chain. The carbohydrate content of component $\mathrm{C} 4$ is $7.0 \%$ (Table 3), and analyses for the $\alpha$-and $\beta$-chains show the $\alpha$-chain to contain the larger part of the carbohydrate. No accurate estimate was obtained for the $\gamma$-chain, though some carbohydrate was present, and it appeared to be in similar content to that of the $\beta$ chains. Fucose was absent and glucose and galactosamine were probably only present in component $\mathrm{C} 4$ as contaminants.

\section{$N$-Terminal amino acid sequences}

$N$-Terminal amino acid determination by the dansyl method gave aspartic acid or asparagine for the $\alpha$-chain, lysine for the $\beta$-chain and glutamic acid or glutamine for the $\gamma$-chain. By using the sequenator, the $N$-terminal amino acids were found to be $\alpha$-chain

Table 2. Amino acid composition of human component C4 and its three polypeptide chains

Abbreviation: n.d., not determined. For details of analysis see the text.

\begin{tabular}{ccccc} 
& \multicolumn{4}{c}{$\begin{array}{c}\text { Amino acid composition } \\
\text { (Residues/100 residues) }\end{array}$} \\
\cline { 2 - 5 } Amino acid & \multicolumn{1}{c}{ C4 } & $\alpha$-Chain & $\beta$-Chain & $\gamma$-Chain \\
Cys & $1.47^{*}$ & $1.36 \ddagger$ & $1.12 \ddagger$ & $3.51 \ddagger$ \\
Asp & 8.14 & 8.45 & 8.02 & 6.76 \\
Thr & 5.29 & 5.98 & 5.06 & 5.02 \\
Ser & 8.19 & 7.71 & 9.12 & 7.13 \\
Glu & 11.87 & 13.03 & 10.52 & 13.99 \\
Pro & 5.60 & 5.33 & 6.69 & 4.65 \\
Gly & 7.48 & 7.74 & 8.77 & 6.53 \\
Ala & 7.92 & 8.87 & 6.29 & 7.95 \\
Val & 7.71 & 7.32 & 8.45 & 7.88 \\
Met & $1.51 \dagger$ & 1.57 & 1.38 & 1.40 \\
Ile & 3.09 & 3.17 & 4.22 & 1.89 \\
Leu & 11.05 & 11.85 & 10.55 & 10.46 \\
Tyr & 3.31 & 2.52 & 3.07 & 4.79 \\
Phe & 3.79 & 3.24 & 4.34 & 4.00 \\
His & 2.44 & 2.46 & 2.35 & 2.26 \\
Lys & 4.45 & 4.11 & 5.04 & 3.78 \\
Arg & 5.41 & 5.30 & 5.05 & 8.03 \\
Trp & 1.19 & n.d. & n.d. & n.d.
\end{tabular}

* Measured as cysteic acid.

$\dagger$ Measured as methionine sulphone.

$\ddagger$ Measured as $S$-carboxymethylcysteine.
Table 3. Carbohydrate analysis of component $C 4$ and of the $\alpha$ - and $\beta$-chains

Carbohydrate composition (residues/100 amino acid residues)

\begin{tabular}{lccc}
\multicolumn{1}{c}{ Sugar } & C4 & $\alpha$-Chain & $\beta$-Chain \\
Fucose & 0 & 0 & 0 \\
Mannose & 1.4 & 1.2 & 1.6 \\
Galactose & 0.8 & 1.0 & 0.4 \\
Glucose & $\leqq 0.07$ & $<0.1$ & $<0.1$ \\
Galactosamine & 0 & 0 & $<0.1$ \\
Glucosamine & 0.8 & 1.1 & 0.6 \\
Sialic acid & 1.0 & 1.5 & 0.7 \\
Carbohydrate (\% of total & 7.0 & 8.6 & 5.6 \\
$\quad$ weight of protein) & & &
\end{tabular}

Table 4. Sequence analysis of the $\mathrm{N}$-terminal residues of $\alpha$-chain of component $C 4$

Component $\mathrm{C} 4 \alpha$-chain $(90 \mathrm{nmol})$ was subjected to automated Edman degradation. Yields ranged from $6-10 \%$ in steps $1-5$ down to $2-3 \%$ in steps $9-12$, as estimated by amino acid analysis after hydrolysis in HI. Release of radioactivity was not detected. $X$ is unidentifiable residue.

Method of identification of amino acid phenylthiohydantoin derivative

Residue $\overbrace{\text { Amino acid Proposed }}^{\text {Am }}$ no.

$\begin{array}{clll}\text { Val } & \text { Asn } & \text { Asx } & \text { Asn } \\ - & \text { Val } & \text { Val } & \text { Val } \\ \text { - } & \text { Asn } & \text { Asx } & \text { Asn } \\ \text { Phe } & \text { Gln } & \text { Phe } & \text { Phe } \\ \text { - } & \text { Lys } & \text { Lys } & \text { Gln } \\ \text { Ile/Leu } & \text { Ile/Leu } & \text { Lys } & \text { X } \\ \text { - } & \text { Asn } & \text { Asx } & \text { Ile } \\ \text { - } & \text { Glu } & \text { Glx } & \text { Glu } \\ \text { - } & \text { Lys } & \text { Lys } & \text { Lys } \\ \text { - } & \text { Ile/Leu } & \text { Leu } & \text { Leu } \\ - & - & - & \text { X } \\ - & \text { Tyr } & - & \text { X } \\ & & - & \text { Tyr }\end{array}$

asparagine, $\beta$-chain lysine and $\gamma$-chain glutamic acid. It was essential to remove the sodium dodecyl sulphate by extensive dialysis in the presence of Dowex 1 (X8) resin to get satisfactory results in the sequenator. The $\alpha$-chain was soluble in $50 \mathrm{~mm}-\mathrm{NH}_{3}$, the $\beta$-chain in $50 \%(\mathrm{v} / \mathrm{v})$ acetic acid and $\gamma$-chain in $100 \mathrm{~mm}-\mathrm{NH}_{3}$, but all three proteins showed a tendency to detach from the sequenator cup. This probably accounts for the incompleteness of the reaction, which became apparent after several steps of $\alpha$ - and

Vol. 165 
Table 5. Sequence analysis of the $N$-terminal residues of component- $C 4 \beta$-chain

Component-C4 $\beta$-chain (140 nmol) was subjected to automated Edman degradation. Yields ranged from 11 to $4 \%$ as estimated by amino acid analysis after back-hydrolysis with HI. Release of radioactivity was not monitored. $\mathrm{X}$ is unidentifiable residue.

\begin{tabular}{cccc} 
Residue & $\begin{array}{c}\text { Method of identification of amino } \\
\text { acid phenylthiohydantoin derivative }\end{array}$ & Proposed \\
\cline { 2 - 3 } no. & T.l.c. & $\begin{array}{c}\text { Amino acid } \\
\text { analysis }\end{array}$ & $\begin{array}{c}\text { Proquence } \\
\text { seque }\end{array}$ \\
1 & Lys & Lys & Lys \\
2 & - & Pro & Pro \\
3 & - & Arg & Arg \\
4 & Leu/Ile & Leu & Leu \\
5 & Leu/Ile & Leu & Leu \\
6 & Leu/Ile & Leu & Leu \\
7 & Phe & Phe & Phe \\
8 & - & - & X \\
9 & - & Pro & Pro
\end{tabular}

$\beta$-chain degradation. The presence of overlapping residues made the results for the $\alpha$-chain after residue 10 somewhat uncertain, though the presence of a tyrosine residue at position 15 was clear (Table 4). On the $\beta$-chain eight $N$-terminal residues could be identified (Table 5). For automatic degradation of the $\gamma$-chain, the coupling step was repeated in step 1 and the cleavage step repeated in steps 1-3: 19 of the 20 $N$-terminal residues were identified (Table 6), including an $S$-carboxymethylcysteine residue at position 18 as shown by release of radioactivity because iodo[ $\left[1-{ }^{14} \mathrm{C}\right]$ acetamide had reacted with $\mathrm{SH}$ groups after reduction of the component $\mathrm{C} 4$. The reduction was carried out with $20 \mathrm{~mm}$-dithiothreitol in the absence of denaturing agents, and it is likely that most of the cystine bonds split were interchain rather than intrachain bonds (Cecil \& Wake, 1962). The yield of amino acid phenylthiohydantoins from the $\gamma$-chain fell abruptly after position 20 , but the reason for this is not clear, as the next amino acid residue appeared to be arginine.

\section{Discussion}

To investigate the mechanism of activation of the early components of complement by antibodyantigen aggregates it is necessary to isolate in good yield and characterize the six proteins $\mathrm{Clq}, \mathrm{Clr}, \mathrm{Cls}$, $\mathrm{C} 2, \mathrm{C} 4$ and $\mathrm{C} 3$ which are involved. The method described here takes the supernatant from the euglobulin precipitation at $\mathrm{pH} 7.4$ used for isolation of subcomponents C1q, C1r and Cls (Gigli et al., 1976; Sim et al., 1977). The precipitate formed when the $\mathrm{pH}$ of the supernatant is lowered to pH5.5 can
Table 6. Sequence analysis of the first $20 \mathrm{~N}$-terminal residues of component- $C 4 \gamma$-chain

Component-C4 $\gamma$-chain $(95 \mathrm{nmol})$ was subjected to automated Edman degradation. Yields ranged from $13 \%$ in the first step down to $3-4 \%$ in steps $15-18$ and $8 \%$ in step 19 , as estimated by amino acid analysis after back-hydrolysis in HI. $X$ is unidentifiable residue.

\begin{tabular}{|c|c|c|c|c|}
\hline \multirow[b]{2}{*}{$\begin{array}{l}\text { Residue } \\
\text { no. }\end{array}$} & \multicolumn{2}{|c|}{$\begin{array}{l}\text { Method of } \\
\text { identification of } \\
\text { amino acid } \\
\text { phenylthio- } \\
\text { hydantoin } \\
\text { derivative }\end{array}$} & \multirow[b]{2}{*}{$\begin{array}{l}\text { Radioactivity } \\
\text { released } \\
\text { (c.p.m.) }\end{array}$} & \multirow[b]{2}{*}{$\begin{array}{l}\text { Proposed } \\
\text { sequence }\end{array}$} \\
\hline & T.l.c. & $\begin{array}{l}\text { Amino } \\
\text { acid } \\
\text { analysis }\end{array}$ & & \\
\hline 1 & Glu & Glx & 43 & Glu \\
\hline 2 & Ala & Ala & 31 & Ala \\
\hline 3 & - & Pro & 35 & Pro \\
\hline 4 & Lys & Lys & 40 & Lys \\
\hline 5 & Val & Val & 45 & Val \\
\hline 6 & Val & Val & 44 & Val \\
\hline 7 & Glu & Glx & 42 & Glu \\
\hline 8 & Glu & Glx & 46 & Glu \\
\hline 9 & Gln & Glx & 51 & Gln \\
\hline 10 & Glu & Glx & 47 & Glu \\
\hline 11 & - & - & 54 & $\mathrm{X}$ \\
\hline 12 & - & Arg & 55 & Arg \\
\hline 13 & Val & Val & 54 & $\mathrm{Val}$ \\
\hline 14 & - & His & 53 & His \\
\hline 15 & Tyr & Tyr & 54 & \\
\hline 16 & & $\mathrm{Abu}^{*}$ & 62 & Thr \\
\hline 17 & Val & Val & 56 & Val \\
\hline 18 & - & Ala* & 176 & CmCys \\
\hline 19 & Ile/Leu & Ile & 93 & Ile \\
\hline 20 & Trp & - & 70 & Trp \\
\hline
\end{tabular}

* Thr and CmCys ( $S$-carboxymethylcysteine) phenylthiohydantoin derivatives yield Abu (2-aminobutyric acid) and Ala, respectively, on hydrolysis in HI.

be used for the isolation of component C3 (R. R. Porter \& I. Gigli, unpublished work), and this second supernatant is the starting point for the isolation of component C4. As described in Gigli et al. (1976) and Sim et al. (1977), repeated addition of $\operatorname{iPr}_{2} P$-F was necessary for good recoveries of component $\mathrm{C} 4$ and the other components in unactivated form. The purification of the components leads to the separation of the large amount of proteolysis inhibitors present in serum, and it appears likely that there is a continuous activation of small amounts of the proteolytic zymogens which remain as a persistent contaminant during purification.

The yield of component C4 obtained is satisfactory in view of the purification necessary and can be raised considerably by re-running of discarded 


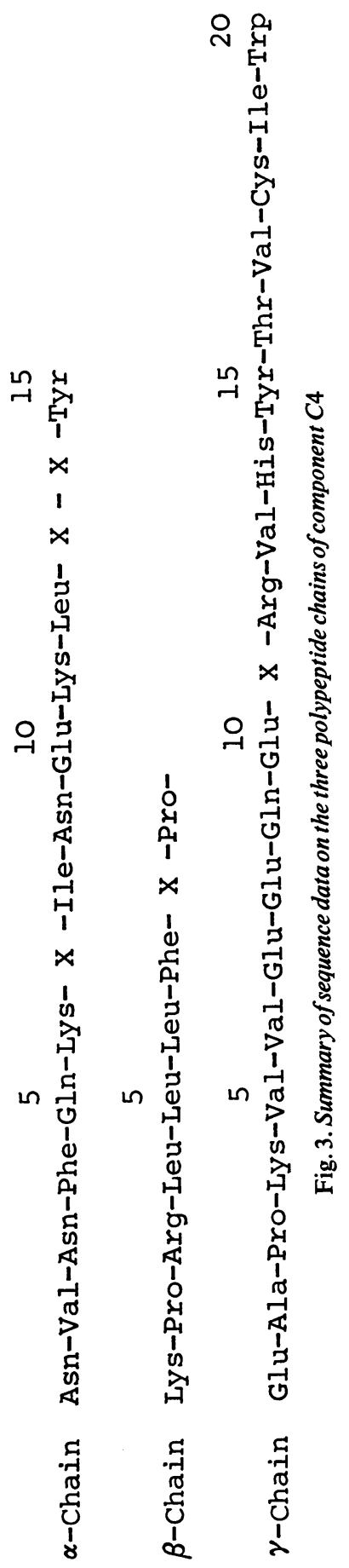

fractions. Difficulty was met in separation of the peptide chains in dissociating solvents such as $1 \mathrm{M}$ acetic acid (Bolotin et al., 1976): 6M-guanidine hydrochloride or sodium dodecyl sulphate solutions were necessary, and ion-exchange chromatography could not be used in these solutions. Fractionation by chromatography on hydroxyapatite columns in sodium dodecyl sulphate solution (Moss \& Rosenblum, 1972) gave satisfactory resolution, but care had to be taken to remove all the detergent subsequently. Separation of the chains by exclusion chromatography in 6M-guanidine hydrochloride was possible, and the guanidine hydrochloride was removed more easily and gave more soluble products, but the yields of the $\alpha$-and $\beta$-chains free of each other were less. Both methods were used and the choice depends on the subsequent investigation to be carried out.

The present results confirm that component $\mathrm{C4}$ contains one of each of three different peptide chains, in agreement with Schreiber \& Müller-Eberhard (1974). A three-chain structure in proteins is exceptional, and there is a possibility that component $\mathrm{C} 4$ is synthesized as one or two chains which are hydrolysed subsequently. If so, the splitting is specific, as no heterogeneity was detected in the $N$-terminal sequences of any chain. Nagasawa \& Stroud (1976) found the $\alpha$-and $\gamma$-chains to have $N$-terminal residues of glutamic acid or glutamine, with that of the $\beta$-chain blocked, but in the present work investigation by dansylation and in the sequenator gave $N$-terminal residues for the $\alpha$-, $\beta$-and $\gamma$-chains of asparagine, lysine and glutamic acid respectively. Carbohydrate is present on all three chains, with the highest amount on the $\alpha$-chain.

It has been suggested that a structural gene for component $\mathrm{C} 4$ may map into the major histocompatibility locus (Teisberg et al., 1976), because the gene coding for one of the peptide chains has arisen by duplication in this complex during evolution (Barnstable et al., 1977). The mol.wt. of the $\gamma$ chain is similar to that of the Ia antigens, i.e. about 30000. The $N$-terminal 20 residues given here for the $\gamma$-chain, however, show no obvious similarity to the sequences reported for the 29000- and 33000-mol.wt. chains of human Ia antigen (Springer et al., 1977). In particular, the sequence in the $\gamma$-chain positions 5-10, Val-Val-Glu-Glu-Gln-Glu, is unusual, and no similarities with other sequences have been found, including the $N$-terminal sequence of component $\mathrm{C} 3$ (Hugli et al., 1975). There was no evidence for $\gamma$-carboxyglutamic acid residues in this sequence, glutamic acid being obtained in good yield in each position. As it is absent from the subcomponents of component $\mathrm{Cl}$, the $\mathrm{Ca}^{2+}$-binding mechanism of complement proteins appears to be different from that of the blood-clotting enzymes (Davie \& Fujikawa, 1975). 
Extension of the structural studies will be necessary to establish the role of component $\mathrm{C} 4$ in the enzymically active $\overline{\mathrm{C} 4-\mathrm{C} 2}$ complex.

We thank Dr. K. B. M. Reid and Miss E. M. Press for much valuable advice, and Miss Jane Addis and Mr. Tony Gascoyne for excellent assistance. I. v. Z. held an E.M.B.O. Fellowship and I. G. a Simon Guggenheim Memorial Foundation Fellowship.

\section{References}

Allen, A. K. \& Neuberger, A. (1975) FEBS Lett. 60, 76-80 Barnstable, C. J., Jones, E. A., Bodmer, W. F., Bodmer, J. G., Arce-Gomez, B., Snary, D. \& Crumpton, M. J. (1977) Cold Spring Harbor Symp. Quant. Biol. 41, in the press

Bolotin, C., Morris, S., Tack, B. \& Prahl, J. (1976) Fed. Proc. Fed. Am. Soc. Exp. Biol. 35, 1762

Brauer, A. W., Margolies, M. N. \& Haber, F. (1975) Biochemistry 14, 3029-3035

Budzko, D. B. \& Müller-Eberhard, H. J. (1970) Immunochemistry 7, 227-234

Cecil, R. \& Wake, R. G. (1962) Biochem. J. 82, 401-412

Clamp, J. R., Bhatti, T. \& Chambers, R. E. (1971) Methods Biochem. Anal. 19, 229-334

Cooper, N. R. (1975) J. Exp. Med. 141, 890-903

Curman, B., Östberg, L., Sandberg, L., MalmhedenEriksson, I., Stålenheim, G., Rask, L. \& Peterson, P. A. (1975) Nature (London) 258, 243-245

Davie, E. W. \& Fujikawa, K. (1975) Annu. Rev. Biochem. 44, 799-829

Gigli, I., Porter, R. R. \& Sim, R. B. (1976) Biochem. J. 157, 541-548

Gray, W. R. (1972) Methods Enzymol. 25, 121-138

Hartree, E. F. (1972) Anal. Biochem. 48, 422-427

Hirs, C. H. W. (1956) J. Biol. Chem. 219, 611-621

Hugli, T. E., Vallota, E. H. \& Müller-Eberhard, H. J. (1975) J. Biol. Chem. 250, 1472-1478
Lachmann, P. J., Grennan, D. \& Martin, A. (1975) Nature (London) 258, 242-243

Lenard, J. (1971) Biochem. Biophys. Res. Commun. 45, 662-668

Liu, T.-Y. \& Chang, Y. H. (1971) J. Biol. Chem. 246, 2842-2848

Lowry, O. H., Rosebrough, N. J., Farr, A. L. \& Randall, R. J. (1951) J. Biol. Chem. 193, 265-275

Meo, T., Krasteff, T. \& Shreffler, D. C. (1975) Proc. Natl. Acad. Sci. U.S.A. 72, 4536-4540

Moss, B. \& Rosenblum, E. N. (1972) J. Biol. Chem. 247, 5194-5198

Nagasawa, S. \& Stroud, R. M. (1976) Fed. Proc. Fed. Am. Soc. Exp. Biol. 35, 654

Nelson, R. A., Jensen, J., Gigli, I. \& Tamura, N. (1966) Immunochemistry 3, 111-135

Patrick, A. R., Taubman, S. B. \& Lepow, I. A. (1970) Immunochemistry 7, 217-225

Reid, K. B. M. (1974) Biochem. J. 141, 189-203

Reid, K. B. M. (1976) Biochem. J. 155, 5-17

Reid, K. B. M. \& Porter, R. R. (1975) Contemp. Top. Mol. Immunol. 4, 1-22

Rosenfield, S. I., Ruddy, S. \& Austen, K. F. (1969) J. Clin. Invest. 48, 2283-2292

Sanger, F. \& Thompson, E. O. P. (1963) Biochim. Biophys. Acta 71, 468-471

Schreiber, R. D. \& Müller-Eberhard, H. J. (1974) J. Exp. Med. 140, 1324-1335

Sim, R. B., Porter, R. R., Reid, K. B. M. \& Gigli, I. (1977) Biochem. J. 163, 219-227

Springer, T., Kaufman, J., Siddoway, L., Gilhart, M., Mann, D., Terhorst, C. \& Strominger, J. (1977) Cold Spring Harbor Symp. Quant. Biol. 41, in the press

Teisberg, P., Olaisen, B., Gedde-Dahl, T., Thorsby, E. \& Åkesson, I. (1976) Nature (London) 264, 253-254

Woods, K. R. \& Wang, K.-T. (1967) Biochim. Biophys. Acta 133, 369-370

World Health Organization (1968) Bull. W.H.O. 39, 935938 